\title{
KENAKALAN ANAK (JUVENILE DELIQUENCY) \\ DAN UPAYA PENANGGULANGANNYA
}

\author{
Raihana
}

ABSTRACT

Children is nation future asset and router generation dream of nation, so children is entitled to the continuity of life, growth and develop, participating and entitled of protection from discrimination and also have civil rights and freedom. Currently juvenile deliquency has leaded into criminal behaviour as the result the case of children in conflict with the law arises. The efforts to overcome the matters of juvenile delinquency is continuously performed. However, such approaches to prevent and to overcome juvenile deliquency that exist today, Some approaches to prevent and address the child's misbehavior is happening this moment appropriate more done through repressive approach. Moreover, imprisonment to children in conflict with the law is still a very prominent way. The appropriate methode and approach to overcome the matters of juvenile delinquency should be performed and based on deep understanding on the causes of juvenile deliquency. There are Penal and Non Penal facility that should be equally in understand and this article aims to discuss the causes of child delinquency is good from the perspective of the theory as well as the concept and also the scope of the law and the method to resolve the delinquency of children in Indonesia.

Keywords: juvenile deliquency, effort to overcome it.

\begin{abstract}
ABSTRAK
Anak adalah aset masa depan bangsa dan generasi penerus mimpi bangsa, sehingga anak-anak berhak atas kelangsungan hidup, tumbuh kembang, berpartisipasi dan berhak akan perlindungan dari diskriminasi dan juga memiliki hak-hak sipil dan kebebasan. Saat ini kenakalan remaja telah bocor ke perilaku kriminal sebagai hasilnya kasus anak yang berkonflik dengan hukum muncul. Upaya untuk mengatasi masalah kenakalan remaja terus dilakukan. Beberapa pendekatan untuk mencegah dan mengatasi kenakalan anak yang terjadi saat ini lebih banyak dilakukan melalui pendekatan represif. Selain itu, penjaraan anak yang berkonflik dengan hukum masih merupakan cara yang sangat menonjol. Metode dan pendekatan untuk mengatasi masalah-masalah kenakalan remaja yang tepat harus dilakukan dan didasarkan pada pemahaman yang mendalam tentang penyebab kenakalan remaja.Ada jalur Pidana dan Non Penal yang harus sama-sama dalam memahami dan artikel ini bertujuan untuk membahas penyebab kenakalan anak baik dari perspektif teori serta konsep dan juga ruang lingkup hukum dan metode untuk menyelesaikan kenakalan anak-anak di Indonesia.
\end{abstract}

Kata kunci: kenakalan remaja, upaya untuk mengatasinya.

\section{PENDAHULUAN}

Akhir akhir ini sering sekali kita mendengar pemberitaan seputar anak, baik anak sebagai korban maupun sebagai Pelaku kenakalan. Masalah kenakalan anak remaja dewasa ini semakin dirasakan meresahkan masyarakat, baik di Negara-negara maju maupun Negara-negara yang sedang berkembang. Dalam kaitan ini, masyarakat Indonesia telah mulai pula merasakan keresahan tersebut, terutama mereka yang berdomisili di kota-kota besar.

Jika kita membicarakan anak sebagai pelaku kenakalan, maka Kenakalan tersebut adalah sebagai salah satu bentuk problema sosial dan merupakan sebuah kenyataan yang harus dihadapi oleh setiap lapisan masyarakat.

Di Indonesia masalah kenakalan anak/remaja dirasa telah mencapai tingkat yang cukup meresahkan bagi masyarakat. Pada masa 
inilah, para anak remaja sering sekali melakukan perbuatan-perbuatan atau tindakan yang menjurus pada perbuatan melawan hukum (weder rech telijkheid) dan merugikan pihak lain seperti perkelahian, pencurian, minum minuman keras, narkoba, menghilangkan nyawa seseorang dan lain sebagainya. Kondisi ini memberi dorongan kuat kepada pihak - pihak yang bertanggung jawab mengenai masalah ini, seperti kelompok edukatif di lingkungan sekolah, kelompok hakim dan jaksa di bidang penyuluhan dan penegakan.

Pada umumnya perilaku kenakalan anak dan remaja dimaknai sebagai suatu bentuk perilaku yang tidak sesuai dengan norma-norma yang hidup di tengah masyarakat. Perilaku anak yang tidak sesuai dengan norma itu dianggap sebagai anak yang cacat sosial (Kartini Kartono, 1988:93) dan kemudian masyarakat menilai cacat tersebut sebagai sebuah kelainan sehingga perilaku mereka pun disebut dengan kenakalan.

Masa remaja secara umum merupakan peralihan transisi dari masa kanak-kanak ke masa remaja. Laporan "United Nations Congress on the Prevention of Crime and Treatment of Offenders"yang bertemu di London pada 1960 menyatakan adanya kenaikan jumlah juvenile delinquency (kejahatan anak remaja) dalam kualitas kejahatan, dan peningkatan dalam kegarangan serta kebengisannya yang lebih banyak dilakukan dalam aksi-aksi kelompok dari pada tindak kejahatan individual (Minddendorff). Kejahatan yang dilakukan oleh anak-anak muda

\section{PEMBAHASAN}

\section{Pengertian Kenakalan Anak}

Kenakalan anak remaja biasa disebut dengan istilah Juvenile berasal dari bahasa Latin juvenilis, yang artinya anak-anak, anak (yg disebut kenakalan) pada intinya merupakan produk dari kondisi masyarakatnya dengan segala pergolakan sosial yang ada di dalamnya.

Dari fenomena tersebut muncul reaksi masyarakat untuk menanggulanginya yang kemudian diwujudkan dalam bentuk kebijakan kriminal. Upaya penanggulangan dengan pendekatan-pendekatan yang ada saat ini memang memiliki kecenderungan untuk lebih mengutamakan sarana pendekatan represif serta penjatuhan sanksi-sanksi pidana berupa pemenjaraan masih sangat banyak dilakukan, meskipun implikasinya dapat berpengaruh buruk pada masa pertumbuhan dan perkembangan psikis dan fisik seorang anak. Bahkan implikasi tersebut dapat berakibat trauma yang dapat berpengaruh pada kehidupan di masa dewasanya. Upaya penanggulangan kenakalan anak sudah semestinya dimulai dari pengetahuan yang cukup mengenai latar belakang dan sebab musabab perilaku kenakalan tersebut. Untuk itu perlu dirumuskan dan digunakan metode serta pendekatanpendekatan yang tepat dalam upaya penanganan dan penanggulangan perilaku-perilaku kenakalan anak. Pemahaman yang salah mengenai sebab musabab kenakalan anak akan menyebabkan timbulnya pemberian terapi yang salah dalam rangka menyembuhkan dan menanggulangi perilaku kenakalan anak. Kita akan membahas tentang bagaimana kenakalan anak bisa terjadi berdasarkan teori dan konsep dalam juvenile deliquency serta bagaimana penanggulangan kenakalan anak di Indonesia.

muda, ciri karakteristik pada masa muda, sifatsifat khas pada periode remaja, sedangkan delinquent berasal dari bahasa latin "delinquere" yang berarti terabaikan, 
mengabaikan, yang kemudian diperluas artinya menjadi jahat, nakal, anti sosial, kriminal, pelanggar aturan, pembuat ribut, pengacau peneror, durjana dan lain sebagainya. Juveniledelinquencyatau kenakalan remaja adalah perilaku jahat atau kenakalan anak-anak muda, merupakan gejala sakit (patologis) secara sosial pada anak-anak dan remaja yang disebabkan oleh satu bentuk pengabaian sosial, sehingga mereka mengembangkan bentuk perilaku yang menyimpang.

Kenakalan anak remaja meliputi semua perilaku yang menyimpang dari norma- norma hukum pidana yang dilakukan oleh anak remaja. Perilaku tersebut akan merugikan dirinya sendiri dan orang-orang di sekitarnya.

Paul Moedikno memberikan rumusan, mengenai pengertian juvenile Delinquency yaitu sebagai berikut:

a. Semua perbuatan yang dari orang-orang dewasa merupakan suatu kejahatan, bagi anak-anak merupakan delinquency. Jadi semua tindakan yang dilarang oleh hukum pidana seperti mencuri, menganiaya,membunuh dan sebagainya.

b. Semua perbuatan penyelewengan dari norma kelompok tertentu yang menimbulkan keonaran dalam masyarakat.

c. Semua perbuatan yang menunjukan kebutuhan perlindungan bagi sosial, termasuk gelandangan, pengemis dan lainlain.

Jika di tinjauan dari sosiokultural B.Simanjutak,S.H. mendefeniskan kenakalan anak yaitu apabila perbuatan-perbuatan itu bertentangan dengan norma-norma yang ada dalam masyarakat di mana ia hidup atau suatu perbuatan anti sosial di mana di dalamnya terkandung unsur-unsur anti normatif.
Sedangkan menurut Bimo Walgito merumuskan arti selengkapnya dari juvenile delinquency merupakan tiap perbuatan, jika perbuatan tersebut dilakukan oleh orang dewasa, maka perbuatan itu merupakan kejahatan, jadi merupakan perbuatan yang melawan hukum, yang dilakukan oleh anak, khususnya anak remaja. Begitupun dengan Kartono yang menjelaskan bahwa juvenile delinquencymerupakan gejala patologis sosial pada remaja yang disebabkan oleh satu bentuk pengabaian sosial. Akibatnya, mereka mengembangkan bentuk perilaku yang menyimpang.

Lain halnya dengan Fuad Hasan yangMerumuskan definisi delinquency adalah Perbuatan anti sosial yang dilakukan oleh anak remaja yang bilamana dilakukan orang dewasa dikualifikasikan sebagai tindak kejahatan.

Dari sisi hukum, berdasarkan Pasal 1

Butir 2 Undang-Undang Nomor 3 Tahun 1997 tentang Pengadilan Anak, mengkualifikasikan kenakalan anak (anak nakal) sebagai anak yang melakukan tindak pidana dan anak yang melakukan perbuatan yang terlarang bagi anak, baik menurut peraturan perundang-undangan maupun menurut peraturan hukum lain yang hidup dan berlaku dalam masyarakat yang bersangkutan.

Jika melihat bentuknya, Sunarwiyati S, membagi kenakalan anak dan remaja ke dalam tiga tingkatan;

a. Kenakalan biasa,seperti suka berkelahi, suka keluyuran, membolos sekolah, pergi dari rumah tanpa pamit dll.

b. Kenakalan yang menjurus pada pelanggaran dan kejahatan seperti mengendarai mobil tanpa SIM, mengambil barang orangtua tanpa izin, 
c. Kenakalan khusus seperti penyalahgunaan narkotika, hubungan seks di luar nikah, pemerkosaan dan lain lain.

Dari pendapat-pendapat di atas dapat disimpulkan bahwa kecenderungan kenakalan remaja adalah kecenderungan remaja untuk

Faktor Faktor Penyebab Terjadinya

\section{Kenakalan Anak}

Kenakalan anak remaja tidak timbul dan ada begitu saja dalam setiap kehidupan, karena kenakalan-kenakalan tersebut mempunyai penyebab yang merupakan faktorfaktor terjadinya kenakalan anak remaja. Pada awalnya para kriminolog mengasumsikan bahwa unsur-unsur niat dan kesempatan sangat berpengaruh terhadap sebab-sebab timbulnya kejahatan atau kenakalan anak. Pada unsur niat terkait dengan faktor-faktor endogen dan eksogen.

a. Faktor endogen adalah faktor-faktor yang berasal dari dalam diri anak itu sendiri yang mempengaruhi tingkah lakunya, antara lain: - cacat yang bersifat biologis dan psikis;

- perkembangan kepribadian dan intelegensi yang terhambat sehingga tidak bisa menghayati norma-norma yang berlaku.

b. Faktor-faktor eksogen adalah faktor berasal dari luar diri anak yang dapat mempengaruhi tingkah lakunya.

Sedangkan menurut Tannebaum, bahwa sebagaimana kejahatan, terjadinya delinkuensi anak itu karena adanya konflik antara suatu kelompok (group) dengan masyarakat (community) yang lebih luas. Oleh karena itu, permasalahan kenakalan anak atau delinkuensi anak bukan hanya disebabkan oleh faktor biologis dan psikologis anak saja. Faktor melakukan tindakan yang melanggar aturan yang dapat mengakibatkan kerugian dan kerusakan baik terhadap dirinya sendiri maupun orang lain yang dilakukan remaja di bawah umur 17 tahun.

sosial, khususnya lingkungan pergaulannya (peers group), dapat menjadi salah satu sebab utama terjadinya kenakalan tersebut.

Menurut Walter Luden, factor-faktor yang berperan dalam timbulnya kenakalan adalah sebagai berikut:

a. Gelombang urbanisasi remaja dari desa ke kota-kota jumlahnya cukup besar dan sukar dicegah.

b. Terjadinya konflik antara norma adat pedesaan tradisional dengan norma-norma baru yang tumbuh dalam proses dan pergesaran sosial yang cepat, terutama di kota-kota besar.

c. Memudarnya pola-pola kepribadian individu yang terkait kuat pada pola kontrol sosial tradisional, sehingga anggota masyarakat terutama remajanya menghadapi "samarpola" untuk melakukan perilakunya.

d. Berkembangnya kenakalan anak remaja yang disebabkan oleh dampak negatif dari perubahan global yang cepat meliputi ilmu pengetahuan dan teknologi sehingga anak melakukan perbuatan di luar kesadarannya.

Dalam pergaulan sehari-hari sebagai makhluk sosial, maka baik penjahat maupun anak delinkuen itu hidup di tengah-tengah masyarakat bersama-sama dengan suatu kelompok tertentu. Kalau seseorang yang normal mungkin tidak mengalami kesulitan menyesuaikan dirinya dengan kelompoknya. Namun tidak demikian kalau seseorang itu 
dalam kondisi atau keadaan tidak normal, ia akan mengalami kesulitan menyesuaikan dirinya dengan kelompok yang lebih besar. Dalam hal ini, Tannebaum berpendapat bahwa kelompok dimana seseorang hidup dan melangsungkan kegiatannya dapat berpengaruh terhadap tingkah lakunya. Apalagi jika seseorang itu masih termasuk dalam kelompok anak yang masih labil kepribadiannya dan masih dalam tahap pencarian jati dirinya. Mereka inilah yang dengan mudah dapat dipengaruhi ataupun diprovokasi oleh hal-hal negatif yang menjurus pada pelanggaran, baik pelanggaran norma hukum maupun pelanggaran norma yang lain.

Bagi anak, lingkungan pergaulan (peer group) yang jelek atau buruk cenderung dapat mendorong terbentuknya perilaku yang buruk (negatif) pula, yang bahkan dapat menjurus pada perilaku yang melanggar hukum, baik dalam taraf yang ringan (mengutil atau mencuri) sampai yang berat (menganiaya atau membunuh). Bahkan dengan maraknya kasuskasus perkelahian antar pelajar, maka lingkungan pergaulan yang buruk merupakan tempat yang potensial bagi kausa terjadinya kenakalan anak. Kasus-kasus school bullying yang terjadi di antara pelajar, geng nero yang merupakan identifikasi kumpulan anak perempuan nakal, atau pun kasus tawuran antar sekolah merupakan beberapa contoh yang perlu dicermati dan diantisipasi oleh pihak-pihak yang berwenang di Indonesia dengan upaya penanggulangan yang terkoordinasi dan terintegarsi dengan baik.

Terkait school bullying (Sarwirini, 2009), kenakalan murid yang tidak diantisipasi sejak awal dapat menimbulkan kemarahan gurunya sehingga khilaf melakukan pemukulan pada muridnya. Hal-hal semacam ini perlu segera diantisipasi dan dilakukan koordinasi di antara orangtua murid, dewan pengawas sekolah dan aparat penegak hukum sehingga dapat mengantisipasi dampak negatif akibat pergaulan yang tidak sehat di sekolah.

Beberapa Teori yang melatar belakangi prilaku nakal yang dilakukan oleh anak, adalah sebagai berikut:

\section{a. Teori Kontrol Sosial}

Teori Kontrol Sosial atau sering disebut Teori Kontrol, berangkat dari asumsi dasar bahwa individu dalam masyarakat mempunyai kecenderungan yang sama kemungkinannya menjadi baik atau jahat. Baik jahatnya seseorang sepenuhnya tergantung pada masyarakatnya. Ia menjadi baik kalau masyarakatnya membuatnya baik dan menjadi jahat apabila masyarakatnya membuatnya menjadi jahat. penganut paham ini berpendapat bahwa ikatan sosial (social bond) seseorang dengan masyarakatnya dipandang sebagai faktor pencegah timbulnya penyimpangan. Seseorang yang lemah atau terputus ikatan sosialnya dengan masyarakat, dapat bebas melakukan penyimpangan.

b. Teori Subkultur Delinkuen

Teori ini dapat ditemukan dalam bukunya Albert K. Cohen (1955) yang berjudul Delinkuen Boys, The Culture of The Gang. Fokus perhatiannya terarah pada satu pemahaman bahwa perilaku delinkuen di kalangan usia muda, kelas bawah merupakan cerminan ketidakpuasan terhadap norma-norma dan nilai-nilai kelompok kelas menengah dan mendominasi kultur masyarakat. Karena kondisi sosial yang ada dipandang seabagai kendala upaya mereka untuk mencapai kehidupan sesuai dengan trend yang ada, sehingga mendorong 
kelompok usia muda kelas bawah mengalami konflik budaya, yang disebut status frustation.

Akibatnya,meningkatkan keterlibatan anak-anak kelas bawah itu pada kegiatan geng-geng dan berperilaku menyimpang yang sifatnya "nonutilitarian, nonmaliciaous and nonnegatistics" (Albert K. Cohen, 1955).

Lebih lanjut R.A. Cloward dan L.E. Ohlin mengemukakan teori yang disebut Differential Opportunity System. Teori ini mengemukakan bahwa penyimpangan di suatu wilayah perkotaan merupakan fungsi dari perbedaan kesempatan yang dimiliki anak-anak untuk mencapai, baik tujuan yang legal maupun yang ilegal. Manakala kesempatan untuk memperoleh yang legal terblokir maka tindak kriminal pun mungkin terjadi, sehingga kecenderungan keterlibatan pada penggunaan narkotika atau dengan kekerasan juga dapat terjadi. Sub budaya yang mungkin terjadi menurut Cloward dan Ohlin dikelompokkan menjadi 3 (tiga) bentuk yaitu:

1. Criminal subcultur, bentuk-bentuk perilaku geng yang ditujukan untuk kepentingan pemenuhan uang atau harta benda;

2. Conflict subcultur, bentuk geng yang berusaha mencari status dengan menggunakan kekerasan;

3. Reatreatist subcultur, bentuk geng dengan ciri-ciri penarikan diri mencari pelarian dengan menyalahgunakan obat atau narkotika atau sejenisnya.

c. Teori Anomi

Teori Anomi diajukan oleh Robert K. Merton, dimana dalam teorinya mencoba melihat keterkaitan antara tahap-tahap tertentu dari struktur sosial dengan perilaku delinkuen, ia melihat bahwa tahapan tertentu dari struktur sosial akan menumbuhkan suatu kondisi dimana pelanggaran terhadap norma-norma kemasyarakatan merupakan wujud reaksi normal (jadi seolah-olah terjadi keadaan tanpa norma atau anomi).

Dalam teori anomi terdapat dua unsur yang dijadikan perhatian dalam mempelajari berbagai bentuk perilaku delinkuen yaitu unsur struktur sosial dan budaya. Unsur budaya menghasilkan goals yang berarti adanya tujuan-tujuan dari kepentingankepentingan yang sudah membudaya, yang meliputi kerangka aspirasi dasar manusia, seperti dorongan untuk hidup. Tujuan tersebut merupakan bentuk kesatuan dan didasari oleh urutan nilai dalam berbagai tingkatan perasaan dan makna. Sedangkan unsur struktural menimbulkan adanya means yang berarti bahwa adanya aturan-aturan dan caracara kontrol yang melembaga dan diterima sebagai sarana untuk mencapai tujuan yang telah membudaya dalam masyarakat.

d. Teori Belajar

Teori Belajar (Social Learning Theory), dikembangkan oleh Ronald Akkers yang dikaitkan dengan delinkuensi anak. Pendekatannya berpegang pada asumsi, bahwa perilaku seseorang dipengaruhi oleh pengalaman belajar. Pengalaman kemasyarakatan disertai nilai-nilai dan penghargaan dalam kehidupan di masyarakat.

Secara umum, teori ini berpandangan bahwa anak-anak akan memperagakan perilakunya atas dasar:

1). Reaksi yang diterimanya dari pihak lain (positif atau negatif),

2). Perilaku orang dewasa yang mempunyai hubungan dekat dengan mereka (utamanya orangtua),

3). Perilaku yang mereka lihat di TV maupun di bioskop. 
Apabila seorang anak mengamati perilaku agresif, misalnya orang dewasa menampar atau memukul orang lain saat bertengkar, dan apabila anak melihat bahwa perilaku agresif diperbolehkan atau mendatangkan hadiah (pujian), akan terjadi kecenderungan anak akan bereaksi dengan cara kekerasan selama ia mengalami kejadian serupa.

Akhirnya anak pun akan menguasai teknikteknik agresifitas dan akan semakin yakin bahwa penggunaan kekerasan itu akan mendatangkan hadiah (pujian). Dampaknya, pengikut teori ini menyatakan seorang anak yang tumbuh kembang dalam lingkungan rumah dimana kekerasan menjadin kebiasaan, maka anak pun akan belajar untuk meyakini bahwa perilaku seperti itu dapat diterima dan mendatangkan hadiah atau pujian (Paulus Hadisuprapto, 1997).

\section{e. Teori Kesempatan}

Teori kesempatan berangkat dari asumsi dasar bahwa terdapat hubungan yang kuat antar lingkungan kehidupan anak, struktur ekonomi dan pilihan perilaku yang diperbuat selanjutnya. Richard A. Cloward dan Lioyn Ohlin berpendapat bahwa munculnya subculture delinkuen dan betuk-bentuk perilaku yang muncul dari hal tsb, tergantung pada kesempatan, baik kesempatan patuh norma maupun kesempatan penyimpangan norma. Apabila kelompok anak (dalam status ekonomi dan lingkungannya itu) terblokir oleh kesempatan patuh norma dalam rangka mencapai sukses hidupnya, mereka akan mengalami frustrasi (status frustation), tanggapan mereka dalam menanggapi frustasi statusnya, sangat tergantung pada terbukanya struktur kesempatan yang ada di hadapan mereka (Richard A. Cloward dan Lloyn Ohlin, 1960).

Teori-teori di atas dapat dijadikan bahan pertimbangan dalam menanggulangi kejahatan yang dilakukan oleh anak, sehingga latar belakang anak melakukan kejahatan dipahami dengan tepat, untuk diterapkan kebijakan penanggulangan dengan tepat pula.

\section{Upaya penanggulangan kenakalan Anak}

Upaya penanggulangan kenakalan anak memang harus benar-benar dilakukan sedini mungkin, anak-anak delinkuen jika tidak ditangani secara benar akan dapat berkembang menjadi penjahat (criminal) pada masa dewasanya. Di lain pihak, kejahatan atau kenakalan anak itu sendiri sangat kompleks, oleh karena itu banyak teori atau pendekatan yang membahas permasalahan kenakalan anak. Dalam perspektif kriminologi, para ahli sering membahasnya melalui pendekatan-pendekatan (approaches) biologis, psikologis, dan sosial. Dalam era modern saat ini terdapat kecenderungan bahwa faktor lingkungan dapat menjadi salah satu faktor dominan yang menyebabkan terjadinya kenakalan anak. Selain itu, dari faktor lingkungan pula dapat digunakan sebagai salah satu sarana (solusi) dalam upaya penanggulangan kenakalan anak. Lingkungan di mana anak tumbuh dan berkembang sesungguhnya ikut bertanggungjawab dalam upaya menanggulangi kenakalan anak. Dalam perspektif kriminologi banyak teori atau konsep yang dikemukakan dalam rangka mencari solusi upaya menanggulangi kenakalan anak. Polapola prevensi, represif, dan kuratif seharusnya diterapkan secara tepat sehingga dapat mencapai hasil yang maksimal. 
Berikut pola yang dapat dilakukan dalam upaya penanggulangan masalah kenakalan anak remaja

\section{a. Upaya Preventif}

Upaya pencegahan terjadinya kenakalan remaja secara umum.

1. Mengenal dan mengetahui ciri umum dan khas remaja

2. Mengetahui kesulitan-kesulitan yang secara umum dialami oleh para anak. Kesulitankesulitan manakah yang biasanya menjadi sebab timbulnya penyaluran dalam bentuk kenakalan.

3. Usaha pembinaan remaja :

a. Menguatkan sikap mental remaja supaya mampu menyelasaikan persoalan yang dihadapinya.

b. Memberikan pendidikan bukan hanya dalam penambahan pengetahuan dan keterampilan melainkan pendidikan mental dan pribadi melalui pengajaran agama, budi pekerti dan etiket.

c. Menyediakan sarana-sarana dan menciptakan suasana yang optimal demi perkembangan pribadi yang wajar.

d. Usaha memperbaiki keadaan lingkungan sekitar, keadaan sosial keluarga maupun masyarakat di mana terjadi banyak kenakalan remaja.

Dengan usaha pembinaan yang terarah para remaja akan mengembangkan diri dengan baik sehingga keseimbangan diri akan tercapai dimana terciptanya hubungan yang serasi antara aspek rasio dan aspek emosi. Pikiran yang sehat akan mengarahkan mereka keperbuatan yang pantas, sopan dan bertanggungjawab yang diperlukan dalam menyelasaikan kesulitan atau persoalan masing-masing.

\section{b. Upaya represif}

Usaha menindak pelanggaran normanorma sosial dan moral dapat dilakukan dengan mengadakan hukuman terhadap setiap perbuatan pelanggarannya.

Pada umumnya tindakan represif diberikan dalam bentuk memberikan peringatan secara lisan maupun tulisan kepada pelajar dan orang tua, melakukan pengawasan khusus oleh kepala sekolah dan team guru atau pembimbing dan melarang bersekolah untuk sementara atau seterusnya tergantung dari macam pelanggaran tata tertib sekolah yang digariskan.

Usaha prefentif kenakalan anak dengan cara abolisionistis adalah untuk mengurangi, bahkan untuk menghilangkan sebab-sebab yang mendorong anak melakukan perbuatanperbuatan delinquen dengan bermotif apa saja. Di samping itu tidak kalah pentingnya usaha untuk memperkecil, bahkan meniadakan faktorfaktor yang membuat anak remaja terjerumus ke dalam perbuatan-perbuatan delinquen. Konsepkonsep tersebut diatas memerlukan realisasi dalam kehidupan masyarakat. Dapat dipastikan pelaksanaan prevensi tidak mungkin apabila hanya dilaksanakan oleh masing-masing lembaga secara sendiri-sendiri. Akan tetapi pelaksanaan tersebut memerlukan kerjasama yang erat satu sama lain.

\section{c. Upaya kuratif}

Dilakukan setelah tindakan pencegahan lainnya dilaksanakan dan dianggap perlu mengubah tingkah laku si pelanggar anak remaja itu dengan memberikan pendidikan. 
Tindakan-tindakan kuratif bagi usaha penyembuhan anak delinquen juga antara lain berupa:

a. Menghilangkan semua sebab-musabab timbulnya kenakalan remaja, baik yang berupa pribadi familiar, sosial dan kultural.

b. Melakukan perubahan lingkungan dengan jalan mencarikan orang tua angkat/asuh dan memberikan fasilitas yang diperlukan bagi perkembangan jasmani dan rohani yang sehat bagi anak - anak remaja.

c. Memindahkan anak - anak ke sekolah yang lebih baik, atau ke tengah lingkungan sosial yang baik.

d. Memberikan tempat latihan bagi para remaja untuk hidup teratur, tertib dan berdisiplin.

e. Memanfaatkan waktu senggang di kamar latihan, untuk membiasakan diri bekerja, belajar dan melakukan rekreasi sehat dengan disiplin tinggi.

f. Menggiatkan organisasi pemuda dengan program - program latihan vokasional untuk mempersiapkan anak remaja delinquen itu bagi pasaran kerja dan hidup di tengah masyarakat.

g. Mendirikan klinik psikologi untuk meringankan dan memecahkan konflik emosional dan gangguan kejiwaan lainnya.

h. Memberikan pengobatan medis dan terapi psikoanalitis bagi mereka yang mengalami gangguan kejiwaan.

\section{d. Upaya pre-emtif}

Upaya-upaya awal yang dilakukan dalam penanggulangan kejahatan untuk mencegah terjadinya tindak pidana secara dini. Usaha-usaha yang dilakukan dalam penanggulangan kejahatan secara pre-emtif adalah menanamkan nilai-nilai atau norma- norma yang baik sehingga norma-norma tersebut terinternalisasi dalam diri seseorang. Kenakalan-kenakalan yang dilakukan oleh anak-anak dan remaja seyogiyanya diupayahkan penanggulangan secara sungguh-sungguh dalam arti penanggulangan yang setuntas-tuntasnya, upaya ini merupakan aktivitas yang pelik apabila ditinjau secara integral, akan tetapi apabila ditinjau secara terpisah-pisah maka upaya ini merupakan kegiatan yang harus dilakukan secara profesional yang menuntut ketekunan dan berkesinambungan dari suatu kondisi menuju kondisi yang lain.

Kondisi fisik dan sosial lingkungan keluarga dan pergaulan anak remaja harus diusahakan positif dan kondusif bagi perkembangan jiwa anak remaja yang sedang dalam tahap labil atau peralihan dari anak-anak ke dewasa untuk menemukan jati dirinya. Dengan faktor- faktor diatas, diharapkan anak remaja bisa menempuh masa-masa sulitnya dengan positif dan berhasil guna bagi kehidupan dewasanya kelak.

\section{Upaya Penanggulangan anak nakal dalam perspektif kriminologi}

Upaya penanggulangan kejahatan pada umumnya dan perilaku delikuensi anak pada khususnya dalam hukum pidana dikenal apa yang disebut Kebijakan Kriminal. Usaha rasional masyarakat untuk menanggulangi kejahatan (termasuk perilaku delinkuenasi anak). Kebijakan kriminal dalam gerak langkahnya dapat dilakukan lewat sarana penal (Hukum Pidana) dan sarana non penal (diluar hukum Pidana). Kedua kebijakan tersebut (penal dan non penal) merupakan pasangan yang saling menunjang dalam gerak langkah penanggulangan kejahatan pada umumnya dan 
perilaku delinkuensi anak pada khususnya dimasyarakat.

Upaya penanggulangan kejahatan lewat jalur penal lebih menitikberatkan pada sifat

repressive

(penindasan/pemberantasan/penumpasan)

sesudah kejahatan terjadi, sedangkan jalur nonpenal lebih menitikberatkan pada sifat preventive

(pencegahan/penangkalan/pengendalian)

sebelum kejahatan terjadi.Selain itu,upaya penanggulangan kenakalan anak secara yuridis harus memperhatikan masalah batasan usia anak nakal tersebut yang dapat bertanggungjawab, serta jenis atau bentuk pemidanaan apa yang paling tepat bagi si anak delinquent (sanksi pidana atau tindakan).

Penanggulangan kenakalan dan kejahatan yang dilakukan oleh anak tentunya berbeda dengan penganggulangan kejahatan yang dilakukan oleh orang dewasa. Karena dalam hal ini anak masih sangat rentan baik secara fisik maupun psikisnya.

Asas-asas yang mendasari kebijakan penanggulangan kenakalan anakpun berbeda dengan orang dewasa. Modifikasi langkahlangkah penal maupun non penal dalam politik kriminal bagi kenakalan anak adalah bahwa kebutuhan akan keterpaduan (integritas) antara kebijaksanaan penanggulangan kejahatan dengan politik sosial dan politik penegakan hukum. Dalam konteks kebijakan penanggulangan kenakalan anak dan prilaku kenakalan anak, perlu domodifikasi politik kesejahteraan masyarakat dan politik perlingungan masyarakat secara umum. Secara khusus diarahkan pada plitik kesejahteraan anak dan politik perlindungan hak-hak anak, baik anak pada umumnya maupun anak yang menjadi korban kejahatan orang dewasa (neglected children) maupun korban anak pelaku kenakalan anak (delinquent children), yang dapat dilihat dalam gambar berikut:

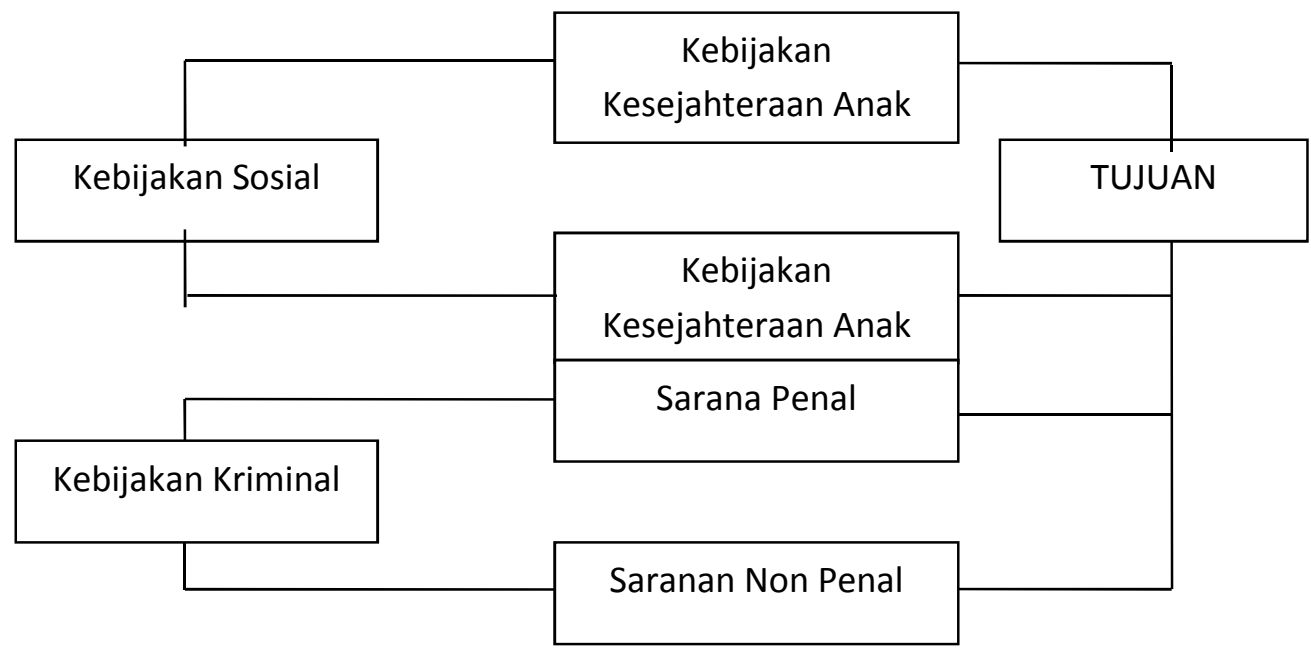

Berkaitan dengan penggunaan sarana penal dan no penal, khusus untuk kebijakan penanggulangan kenakalan anak, kondisinya tidak berbeda. Penggunaan sarana nonpenal diberi porsi yang lebih besar daripada penggunaan sarana penal, berarti ada kebutuhan dalam konteks penanggulangan kenakalan anak, pemahaman yang berorientasi untuk mencapai faktor-faktor kondusif yang menyebabkan timbulnya kenakalan anak (faktor kriminogen). Kriminologi menempati posisi penting, disamping peranan kriminologi yang melalui 
penelitian memahami hakikat dan latar belakang kenakalan anak, juga menelusuri sarana nonpenal, pendekatan kriminologi diperlukan dalam konteks penggunaan sarana penal. Dalam konteks sarana penal, dikenal adanya hukum pidana yang dapat dilihat dalam gambar berikut:

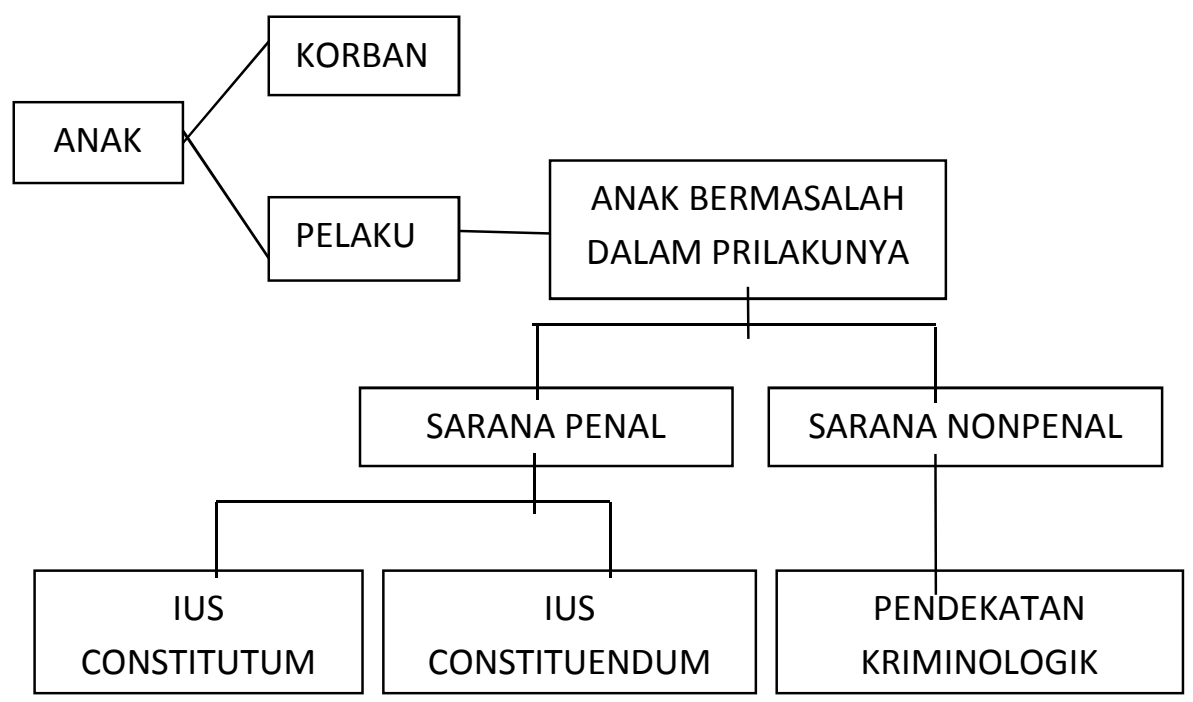

Menurut Soedjono Dirjosisworo

(1984), dalam usaha penanggulangan kejahatan cara umum yang konsepsional, dilakukan dengan memadukan berbagai unsur yang berhubungan dengan mekanisme peradilan pidana serta partisipasi masyarakat, yang dapat dijelaskan sebagai berikut:

a. Peningkatan dan penetapan aparatur penegak hukum, meliputi pemantapan organisasi, peronel dan sarana prasarana untuk penyelesaian perkara pidana.

b. Perundang-undangan yang dapat berfungsi mengkanalisir dan membendung kejahatan dan mempunyai jangkauan ke masa depan.

c. Mekanisme peradilan pidana yang efektif dengan syarat-syarat cepat, tepa, murat dan sederhana.

\section{PENUTUP}

Masa remaja merupakan masa-masa transisi dari anak-anak menuju dewasa. Dalam masa ini para remaja dihadapkan dengan banyak d. Kordinasi antara aparatur penegak hukum dan aparatur pemerintahan lainnya yang berhubungan, untuk meningkatkan daya guna dalam penanggulangan kriminalitas.

e. Partisipasi masyarakat untuk membantu kelancaran pelaksanaan penanggulangan kriminalitas.

Berkaitan dengan proses pengadilan anak (sebagai bentuk upaya penanggulangan yang bersifat represif) seharusnya dilaksanakan dalam rangka menyadarkan anak akan kesalahan yang diperbuatnya. Jangan sampai dalam proses tersebut menyebabkan "trauma" dikemudian hari yang dapat membahayakan tumbuh kembangnya anak tersebut.

persoalan. Kenakalan anak remaja adalah salah satu hal yang menyimpang karena ada pikiran negatif dan pengaruh negatif dalam diri anak remaja. Kenakalan anak remaja merupakan 
refleksi dari perbuatan orang dewasa di segala sector kehidupan yang dipenuhi bayang-bayang hitam dan pergulatan seru (penuh intrik, kekerasan, kekejaman, nafsu kekuasaan, kemunafikan, kepalsuan, dll). Dan disini dukugan dari orang tua, keluarga, teman, dan masyarakat sekitar merupakan salah satu bentuk penguatan remaja untuk lebih bertingkah laku positif.

\section{DAFTAR PUSTAKA}

Cloward, Richard A. dan Lloyn Ohlin, Delinquency and Opportunity: $A$ Theory of Delinquent Gang, New York. 1960.

Cohen, Albert K., Delinquent Boys, The Cultur of The Gang, New York. 1955.

Dirjosisworo, Soedjono, Ruang Lingkup Kriminologi, Bandung: Remadja karya. 1984.

Gultom, Maidin, Perlindungan Hukum Terhadap Anak, Bandung: Refika Aditama, 2010.

Hadisuprapto, Paulus, Delikuensi Anak: Pemahaman dan Penanggulangannya, Malang: Bayumedia. 2008.

Kartini, Kartono, Kenakalan Remaja.Jakarta: PT Raja Grafindo Persada.2005

Lundman, J. Richard, Prevention and Control of Juvenile Deliquency, Oxford: Oxford University Press. 1993.

Purniati, Diktat Kenakalan Anak Dalam Pendekatan Sosiologis, Bahan Ajar Selapa Polri, Jakarta: 2007.

Sarwirini, "Viktimisasi Anak Delinkuen: Studi di Lembaga Pemasyarakatan Anak di Blitar, Laporan Penelitian, Surabaya: Lembaga Perlindungan Anak Jawa Timur, 2001-2002.

$$
\text { Sebab musabab dari timbulnya }
$$

kenakalan anak dan upaya penanggulangannya dapat ditinjau, baik dari perspektif yuridis maupun non yuridis (khususnya kriminologi). Jika kedua perspektif tersebut digunakan secara tepat sesungguhnya akan menunjang Sistem Peradilan Anak yang bertujuan untuk perbaikan dan pertumbuhan fisik dan psikis yang baik, yang berguna bagi perkembangan pribadi dan sosial anak di kemudian hari.

, "Kekerasan terhadap Murid dalam Kasus Bullying", Yustika - Media Hukum dan Keadilan, Vol. 12, No. 2, Universitas Surabaya, Surabaya, 2009.

.Sudarsono,. Kenakalan Remaja. Jakarta: Rineka Cipta. 2004

Undang-undang No. 23 Tahun 2003, tetang Perlindungan Anak 